\title{
Maximizing Production of Estrogen Receptor $\beta$ with the Baculovirus Expression System
}

\author{
BioTechniques 34:334-343 (February 2003)
}

\author{
Peter C. Kulakosky and \\ Carolyn M. Klinge \\ University of Louisville School \\ of Medicine, Louisville, KY, \\ USA
}

\section{INTRODUCTION}

The estrogen receptor (ER), which functions both as a signal transducer and transcription factor that modulates the expression of target genes, is the progenitor for all steroid receptors (42) and is a member of the nuclear receptor superfamily that currently includes 48 known receptors plus two pseudogenes (30). In mammals, ER is encoded by two genes, $\alpha$ and $\beta$ (26). ER $\alpha$ and ER $\beta$ function as dimers (28). To study the functional properties of ER $\alpha$ and ER $\beta$, large quantities of appropriately posttranscriptionally processed proteins are needed for in vitro assays.

Early studies demonstrated that steroid receptors overproduced in yeast (31) or E c coli (37) were generally ineffective for in vitro analyses compared to receptors extracted from animal tissues because of insolubility, proteolysis, inappropriate or missing post-translational modification, and interfering proteins (41). The reasons for the failure of these systems included codon usage, solubility, stability of the protein in the absence of the chaperonin complexes with which steroid receptors interact, the absence of appropriate post-translational modifications, and variations in proteolytic activity (41). The baculovirus expression vector system (BEVS) has been widely adopted for the expression of steroid and nuclear receptors and many other intracellular, secreted, and membrane proteins because it provides a reproducible method for the production of large amounts of recombinant proteins (33). The most widely used virus for BEVS is the $A u$ tographa californica multicapsid nucleopolyhedrovirus (AcMNPV). Al- though a wide variety of cells are susceptible to AcMNPV infection, Spodoptera frugiperda (Sf) cells Sf21 or their subclone Sf9 (Invitrogen, Carlsbad, CA, USA) are generally used for the production of nuclear receptors.

Insect cells have been demonstrated to perform many post-translational modifications that confer correct folding, biological activity, and antigenicity on expressed proteins $(25,32,33)$. These modifications include the phosphorylation, glycosylation, myristylation, and palmitylation, signal peptide processing, post-translational cleavage, and disulfide bond formation (25). The first report of the baculovirus expression of hER $\alpha$ with BEVS (9) used the human estrogen receptor (HEO) clone (18) that was later found to have a single nucleotide change that resulted in a glycine-to-valine amino acid substitution (Gly-400 to Val-400) that decreased $\mathrm{E}_{2}$ binding affinity and destabilized the protein (43). Subsequently, the corrected HEGO clone; that is, with Gly-400 (43), was used to generate a baculovirus for $\mathrm{ER} \alpha$ expression in Sf9 cells $(2-4,10,34)$. Other investigators have expressed hER $\alpha$ in Sf9 cells, either as a wild-type or fusion protein with GST or FLAG $^{\circledR}(6,7,47,48)$. Mouse ER $\alpha(16)$, chicken ER (8), and mouse $\operatorname{ER} \beta(11,12)$ have also been expressed in Sf9 cells, and mouse ER $\alpha$ has been expressed in Sf21 cells (1). Researchers have yet to examine whether insect cell lines differ in the level of ER or other nuclear receptor produced.

To produce the most pure functional receptor while simultaneously conserving costly reagents, we compared the production and functional characteristics of recombinant rat ER $\beta$ driven by a 
recombinant baculovirus in four commonly used insect cell lines: Sf9, Sf21, Tn368, and BTI-TN5b1-4 (High Five $^{\mathrm{TM}}$; Invitrogen). We found that ER $\beta$ expression is highest in Sf21 cells compared to the most commonly used Sf9 cells. The procedure for the infection, harvesting, and characterization of recombinant ER $\beta$ should be applicable to all nuclear receptors as well as other transcription factors.

\section{MATERIALS AND METHODS}

\section{Plasmids and Strains}

The cDNA for rat ER $\beta$ in pCMV5 was generously provided by Dr. J.-A. Gustaffson (27). There were no unique restriction sites near the beginning of the ER $\beta$ open reading frame, so the cDNA sequence was modified by PCR with a primer designed to yield a product that better conforms to base biases near the translation starts in the AcMNPV genome open reading frames (5) and to remove upstream noncoding regions. The PCR product was inserted into the PCR 2.1 plasmid (Invitrogen), which enabled the introduction of an EcoRI restriction site near the translation start site. The upstream region and first part of the open reading frame were sequenced and then subcloned from the PCR 2.1 plasmid, from the plasmid EcoRI site to the first HindIII site in the open reading frame, into the minimal baculovirus transfer plasmid, pBAC-1 (Novagen, Madison, WI, USA), which uses the polyhedrin promoter. The final immediate upstream sequence was 5'-AATTCGGCTTACATG-3'. The transfer plasmid was completed by subcloning the remainder of the open reading frame (HindIIIHindIII) from pCMV5-rat ER $\beta$. pBAC1-ER $\beta$ was co-transfected into IPLBSf21AE cells with BacVector ${ }^{\circledR}-3000$ viral DNA (Novagen) in six-well plates with the Eufectin ${ }^{\mathrm{TM}}$ lipid transfection reagent from the Novagen BacVector3000 transfection kit. The Sf21 cells were overlaid with agarose, and the initial cloning was done directly from the transfected cell monolayer. Clones were purified by repeated plaque purification in Trichoplusia ni (Tn)368 cells cultured in 24-well plates (49).

\section{Baculovirus Titer Determination}

ER $\beta$ baculovirus titer was determined by plaque assay (51) in 24-well plates. Tn368 cells were used because they demonstrate easily recognizable morphological changes in response to infection. In brief, after the optimal density was determined, Tn368 cells were plated in $1 \mathrm{~mL}$ TNM-FH medium (Grace's insect cell medium; Invitrogen) supplemented with $10 \%$ FBS. One-tenth milliliter of serial dilutions of virus stock was used for infection. The cells and virus were sedimented at $1000 \times g$ for $1 \mathrm{~h}$ at $28^{\circ} \mathrm{C}$, and the supernatant medium was aspirated. Each well was overlaid with $0.5 \mathrm{~mL} 0.7 \%$ low-melting agar (Seaplaque ${ }^{\circledR}$; CAMBREX, Rockland, ME, USA) in medium containing 10\% FBS, 50\% TNMFH (Grace's supplemented medium; Invitrogen), and 40\% Grace's medium, Vaughn's modification (JRH Biosciences, Lenexa, KS, USA) after infection and incubated at $28^{\circ} \mathrm{C}$ in passively humidified containers. Plaques were counted three to four days after infection.

\section{Comparison of ER $\beta$ Production between Different Insect Cell Lines}

The viral titer determined by the plaque assay was used for the subsequent infection of the insect cell lines IPLB-SF21AE (Sf21) and Tn368 (generously provided by Alan Wood, Boyce Thompson Institute for Plant Research, Ithaca, NY, USA), Sf9, and BTITN5b1-4. Viable cell counts were determined by Trypan blue staining. For time and cell density experiments, virus was added at a MOI of 10 , and the mixture was diluted for an appropriate cell number in 3 or $3.5 \mathrm{~mL} /$ well (depending on the experiment and always the same within an individual experiment). Cells were plated at the indicated cell densities in six-well plates $\left(9.5 \mathrm{~cm}^{2}\right.$ wells; Corning, Corning, NY, USA) and were infected with the ER $\beta$ baculovirus by sedimentation at $1000 \times g$ for 1 hour at $28^{\circ} \mathrm{C}$. The time after infection was counted from the end of the centrifugation step. The inoculating medium was removed and replaced with fresh medium $(3 \mathrm{~mL} /$ well $)$. The plates were sealed with vinyl electrical tape, placed in pas- sively humidified boxes, and incubated at $28^{\circ} \mathrm{C}$ for the indicated times.

For cell extract preparation, the cells were harvested and sedimented at $66 x$ $g$ for $5 \mathrm{~min}$ in a swinging-bucket rotor (Beckman Coulter, Fullerton, CA, USA). After resuspension, the cells were washed with room temperature isotonic saline $\left(3.7 \mathrm{mM} \mathrm{CaCl}_{2}, 54.7\right.$ $\mathrm{mM} \mathrm{KCl}, 11.2 \mathrm{mM} \mathrm{MgCl} 2,11.3 \mathrm{mM}$ $\mathrm{MgSO}_{4}, 7.3 \mathrm{mM} \mathrm{NaH} \mathrm{PO}_{4}, 181 \mathrm{mM}$ sucrose, $\mathrm{pH}$ 6.5), sedimented, and washed once with room-temperature hypotonic solution $(10 \mathrm{mM}$ Tris- $\mathrm{HCl}$, $\mathrm{pH} 7.5,10 \mathrm{mM} \mathrm{KCl}, 10 \%$ glycerol, 1 mM EDTA, 1 mM DTT, 1 mM PMSF, $2 \mu \mathrm{g} / \mathrm{mL}$ aprotinin, $2 \mu \mathrm{g} / \mathrm{mL}$ leupeptin, $2 \mu \mathrm{g} / \mathrm{mL}$ pepstatin, and $10 \mu \mathrm{g} / \mathrm{mL}$ E64 (Roche Applied Science, Indianapolis, IN, USA). The cells were resuspended in $0.3 \mathrm{~mL}$ ice-cold hypotonic solution, frozen in liquid nitrogen, and stored at $70^{\circ} \mathrm{C}$. Upon thawing, the $\mathrm{KCl}$ and Tris$\mathrm{HCl}$ concentrations were adjusted to $600 \mathrm{mM}$ and $50 \mathrm{mM}$, respectively, and the cells were disrupted using a sonicator (Branson Sonifier model 200; Branson Ultrasonics, Danbury, CT, USA) equipped with a cup horn cooled with ice water. Disruption was monitored with Trypan blue staining and examination with a phase-contrast microscope (Phase Contrast-2 ELWD 0.3; Nikon, Melville, NY, USA). After sonication, the extract was incubated on ice for $3 \mathrm{~h}$ and clarified by sedimentation in a TLS100.2 rotor (Beckman Coulter) at $279000 \times g$ for $15 \mathrm{~min}$. The supernatant solution was aliquoted, frozen in liquid nitrogen, and stored at $-70^{\circ} \mathrm{C}$.

For DNA binding assays, additional concentrated nuclear extracts were prepared. Three insect cell lines, IPLBSF21AE, Sf9, and BTI-TN5b1-4 were plated in $75 \mathrm{~cm}^{2}$ plug-seal cell culture flasks (Corning). Following attachment, the medium was removed, and ER $\beta$ baculovirus was added at an MOI of 10 in a volume of $0.5 \mathrm{~mL}$. The flasks were rocked slowly for $1 \mathrm{~h}$, and then 15 $\mathrm{mL}$ TnM-FH medium (Grace's supplemented medium) and $10 \%$ FBS were added. The flasks were incubated at $28^{\circ} \mathrm{C}$. Nuclear extracts were prepared from Sf21, Sf9, and BTI-TN5b1-4 cells at $1.5,1.8$, and 2.7 days after infection, respectively, for samples early in the infection cycle. For samples late in the infection cycle, Sf21, Sf9, and BTI- 
TN5b1-4 cells were harvested at 2.5, 2.5, and 4.7 days, respectively. At the start of infection, the cells were at densities $\left(\right.$ per $\left.\mathrm{cm}^{2}\right)$ of 77330,200000 , and 72000 for Sf21, Sf9, and BTI-TN5b14 , respectively.

For nuclear extract preparation, the cells were washed once with roomtemperature isotonic saline, followed by a wash with room-temperature hypotonic buffer (described earlier). The cells were resuspended in two packed cell volumes of cold hypotonic solution and allowed to swell on ice for $20 \mathrm{~min}$. A Dounce homogenizer was used to disrupt $90 \%$ of the cells. The homogenate was sedimented at $3200 \times g$ for $20 \mathrm{~min}$. The nuclear pellet was resuspended in extraction buffer (hypotonic buffer with $50 \mathrm{mM}$ Tris- $\mathrm{HCl}$ and $600 \mathrm{mM} \mathrm{KCl}$ as final concentrations) in a volume equal to that used for the homogenization. The samples were sonicated on ice with a sonicator equipped with a stepped microprobe horn. Disruption was monitored with Trypan blue staining and phase-contrast optics. After sonication, the extract was incubated on ice for $3 \mathrm{~h}$ and clarified by sedimentation in the TLS100.2 rotor at $279000 \times g$ for $15 \mathrm{~min}$. The clarified supernatant solution was aliquoted and stored at $-70^{\circ} \mathrm{C}$.

The concentration of ER $\beta$ in each sample was determined by a hydroxylapatite (HAP) assay (36). Cellular or nuclear extracts were incubated in TDPK111 buffer (40 nM Tris-HCl, $\mathrm{pH}$ 7.5, $1 \mathrm{mM}$ DTT, 0.5 mM PMSF, and $111 \mathrm{mM} \mathrm{KCl}$ ) containing $30 \mathrm{nM}$ $\left[{ }^{3} \mathrm{H}\right] \mathrm{E}_{2}\left(\left[2,3,6,7-\left[{ }^{3} \mathrm{H}\right](\mathrm{N})\right] 17 \beta\right.$-estradiol, $74 \mathrm{Ci} / \mathrm{mmol}$, NET-317; $\mathrm{NEN}^{\circledR}$ Life Science Products, Boston, MA, USA) for $1 \mathrm{~h}$ at $37^{\circ} \mathrm{C}$. Following a 1-h incubation with a $10 \%$ HAP solution at $4^{\circ} \mathrm{C}$, the HAP was sedimented and washed three times with $1 \mathrm{~mL}$ TDPK111. The HAP-bound $\left[{ }^{3} \mathrm{H}\right] \mathrm{E}_{2}$ was determined by liquid scintillation counting in Ecoscint $^{\mathrm{TM}}$ A (National Diagnostics, Atlanta, GA, USA) in a Wallac 1409 scintillation counter (Turku, Finland). A 200-fold excess of unlabeled $E_{2}(300$ $\mathrm{nM}$ ) was used as a competitor with $\left[{ }^{3} \mathrm{H}\right] \mathrm{E}_{2}$ for $\mathrm{ER} \beta$ binding as a control to determine nonspecific binding. The specific binding of the $\left[{ }^{3} \mathrm{H}\right] \mathrm{E}_{2}$ was used to calculate the $\operatorname{ER} \beta$ concentration in mols of dimer, assuming that each ER $\beta$ monomer binds one $\left[{ }^{3} \mathrm{H}\right] \mathrm{E}_{2}(27)$. The affinity of the $E_{2}-E R \beta$ interaction was determined by competition binding using the HAP assay (36), in which a fixed amount of ER $\beta$ (1.6 nmol) was incubated with $1.6 \mu \mathrm{M}\left[{ }^{3} \mathrm{H}\right] \mathrm{E}_{2}$ plus increasing concentrations (from $30 \mathrm{fmol}$ to $1 \mu \mathrm{mol}) \mathrm{E}_{2}$. Binding reactions were performed in triplicate within each HAP assay for each time point sample (22). The nonspecific binding did not vary significantly over the time course of infection or with differences in cell density. The data were analyzed by nonlinear regression analysis using GraphPad Prism ${ }^{\circledR}$ (GraphPad Software, San Diego, CA, USA).

\section{Electrophoretic Mobility Shift Assay}

Protein-DNA binding was measured by electrophoretic mobility shift assay (EMSA) as previously described (23,44-46). In brief, identical molar amounts of ER $\beta$, based on the HAP assay results, were incubated with a fixed amount (50000 dpm) [32P]-labeled EREc38 (sequence: 5'-TCAGGTCAGAGTGACCTGAGCTAAAATAACACATTCAG-3') (24). ERß-specific antibodies (Y19) (Santa Cruz Biotechnology, Santa Cruz, CA, USA) and ERß-14C8 (14C8 or 14C) (GeneTex, San Antonio, TX, USA) (40) were included in selected reactions, as indicated in Figure legends. Dried EMSA gels were analyzed using an InstantImager and associated software, the Packard Imager for Microsoft $^{\circledR}$ Windows ${ }^{\circledR}$ v2.04 as previously described (both from Packard Instrument, Meriden, CT, USA) (29). The competition EMSA method for determining the affinity of ER $\beta$-ERE interaction has been previously reported (46).

\section{Western Blot Analysis}

The protein concentration of nuclear extracts was determined using the dextran-coated charcoal (Lowry) assay and BSA as a standard (Bio-Rad Laboratories, Hercules, CA, USA). For Western blotting, $30 \mu \mathrm{g}$ protein from the nuclear extract of baculovirus-infected cells were separated on $10 \%$ SDS polyacrylamide gels and electroblotted onto a PVDF membrane. Following the transfer, the blots were 
probed with ER $\beta$ polyclonal antiserum PA1-311 (Affinity Bioreagents, Golden, $\mathrm{CO}$, USA) or monoclonal ER $\beta$ antibody CWK-F12 that had been generously provided by Dr. Benita S. Katzenellenbogen (13). We used the Renaissance Enhanced Luminol Reagent (NEN Life Science Products) for immunochemical detection as previously described (23). Data were quantitated from scanned films using Un-Scan-It ${ }^{\mathrm{TM}}$ Software ver. 5.1 (Silk Scientific, Orem, UT, USA) (23).

\section{RESULTS}

\section{Maximizing BEVS ER $\beta$ Production}

We examined ER $\beta$ production as a function of cell density and time after infection in four insect cell lines: Tn368, BTI-TN5b1-4, Sf9, and Sf21. Each insect cell line was infected at six different cell densities. The specific $\left[{ }^{3} \mathrm{H}\right] \mathrm{E}_{2}$ binding capacity was determined as a measure of functional ER $\beta$ production. Preliminary observations with all four cell lines [IPLB-SF21AE (Sf21), Sf9, Tn368, and BTI-TN5b1-4] revealed that $\operatorname{Tn} 368$ was a comparatively poor producer of recombinant rat ER $\beta$ (data not shown).

We continued the investigation with Sf9 (the cell line used most often for the production of nuclear receptors), Sf21, and BTI-TN5b1-4. A series of densities of cells were infected at a MOI of 10. Phase-contrast microscope observations of the cells $24 \mathrm{~h}$ after infection revealed nearly synchronous in-

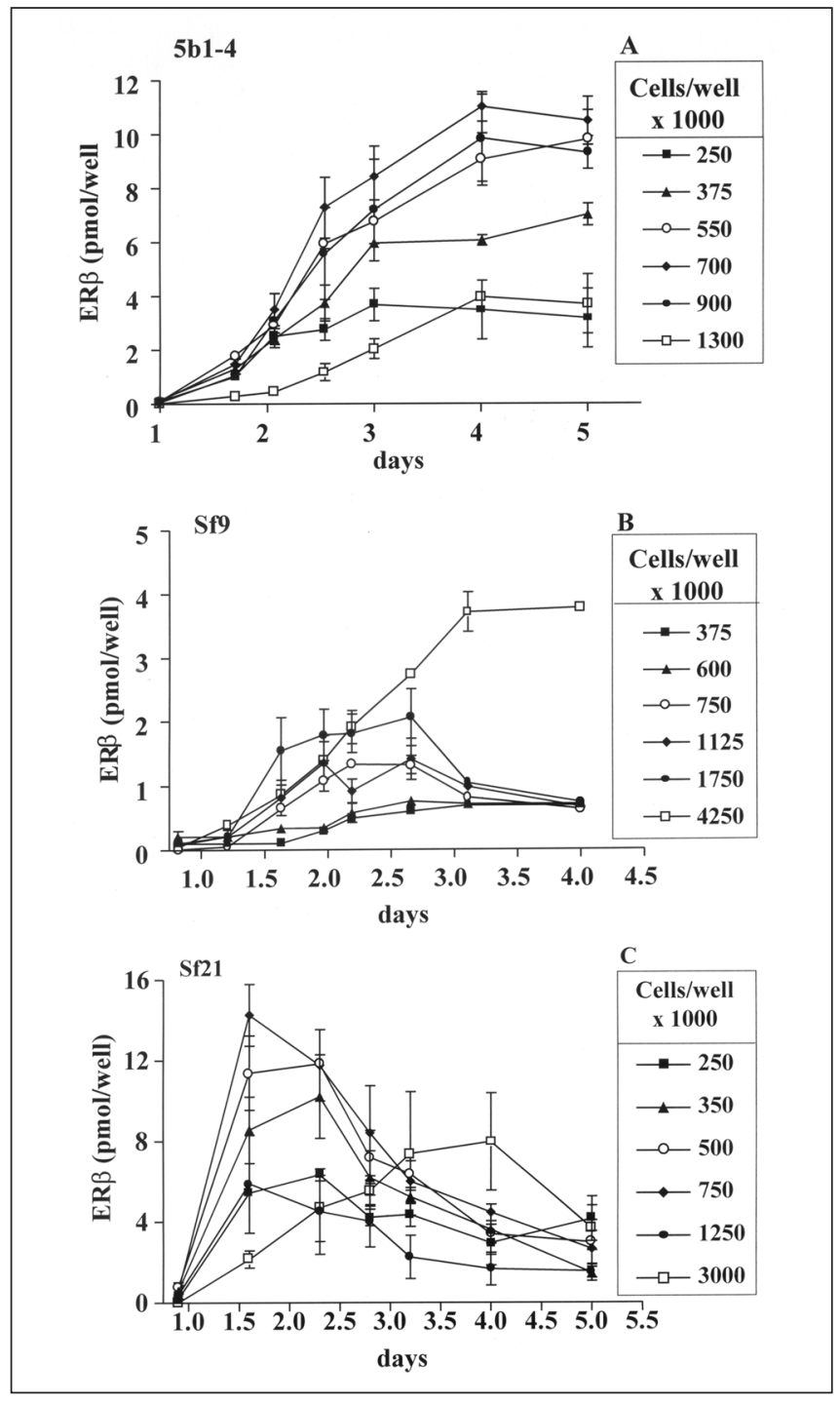

Figure 1. Quantitation of ER $\beta$ production on a per well basis in insect cell lines. The indicated insect cell lines in panels A-C, representing BTITN5b1-4, Sf9, and Sf21 cells, respectively, were plated at the indicated cell densities and infected with ER $\beta$ baculovirus, as described in the Materials and Methods section. Cells were harvested at the indicated number of days post-infection, and the ER $\beta$ concentration was determined by $\left[{ }^{3} \mathrm{H}\right] \mathrm{E}_{2}$ binding. Values are $\bar{x} \pm$ SEM of two to three separate experiments in which each time point was performed in triplicate.

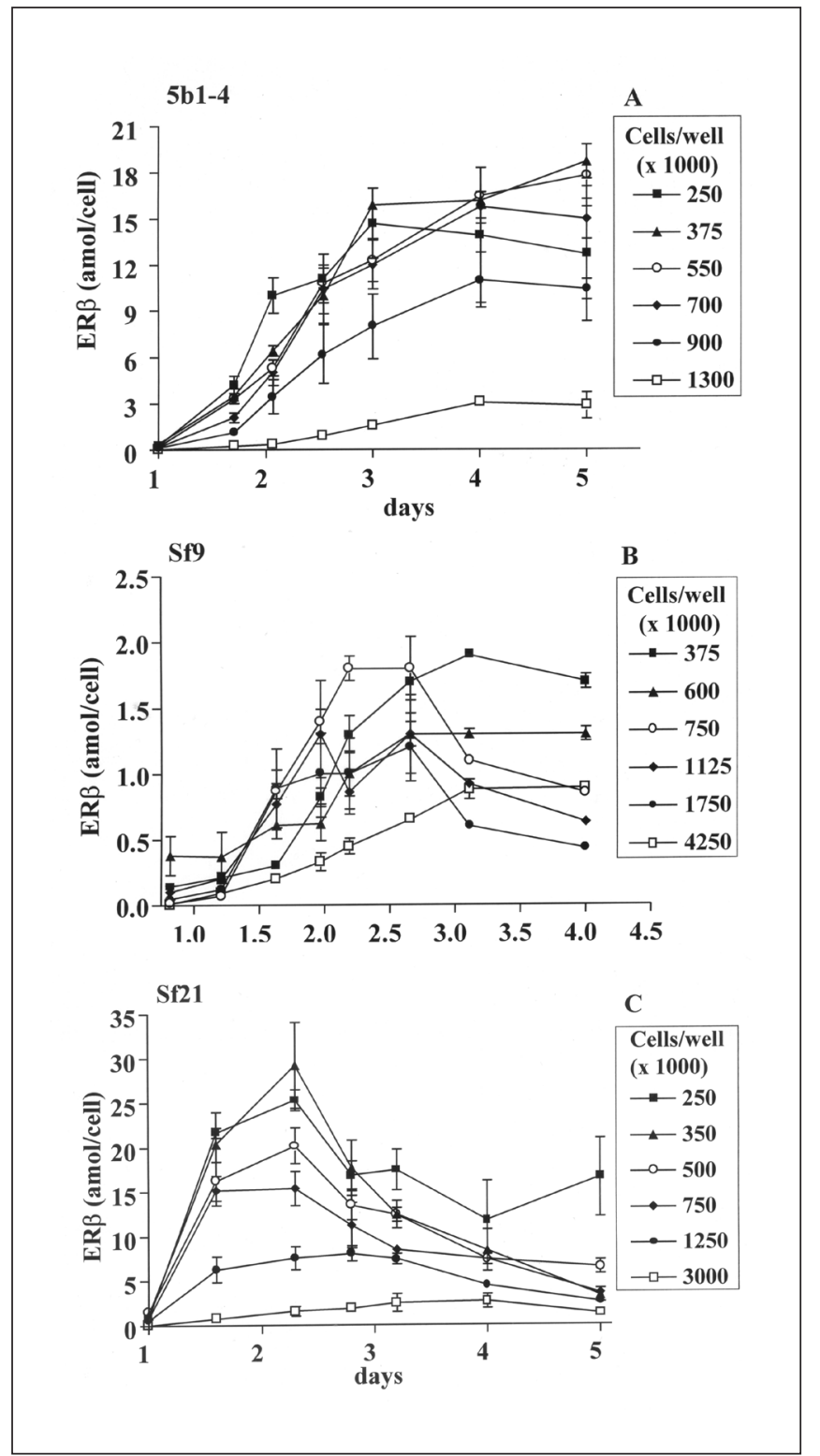

Figure 2. Comparison of ER $\beta$ production on a per cell basis in insect cell lines. The data in Figure 1 are expressed on a per cell basis. Values are $\bar{x} \pm$ SEM of two to three separate experiments in which each time point was performed in triplicate. 


\section{Research Report}

Table 1. Comparison of ER $\beta$ Production in Insect Cell Lines

\begin{tabular}{|c|c|c|c|c|c|}
\hline Cell Line & $\begin{array}{l}\text { Optimal Cells/ } \\
\text { Well and Time } \\
\text { After Infection }\end{array}$ & $\begin{array}{c}\text { Maximum ER } \beta \\
\text { Protein Production } \\
(\mathrm{pmol} / \text { well) }\end{array}$ & $\begin{array}{c}\text { Maximum ER } \beta \\
\text { Protein Production } \\
\text { (amol/cell) }\end{array}$ & $\begin{array}{c}\text { Maximum ER } \beta \\
\text { Protein Production } \\
\text { (pmol/mg protein) }\end{array}$ & $\begin{array}{c}\text { ER } \beta \text {-ERE Binding } \\
\% \text { of [32P]ERE } \\
\text { Bound/Total } \\
\text { [32P]ERE }\end{array}$ \\
\hline BTI-TN5b1-4 & $7 \times 10^{5}$ at 4.2 days & 11.5 & 17 & 4 & 17 \\
\hline Sf9 & $1.9 \times 10^{6}$ at 2.2 days & 2.5 & 1.5 & 9 & 20 \\
\hline Sf21 & $7.5 \times 10^{5}$ at 1.6 days & 15 & 20 & 18 & 27 \\
\hline
\end{tabular}

fection with the exception of the highest cell density in which the cells continued to divide, further increasing cell density. For BTI-TN5b1-4 cells (Figure $1 \mathrm{~A})$, ER $\beta$ production increased with cell density up to $7 \times 10^{5}$ cells/well. At higher cell densities, ER $\beta$ production decreased. BTI-TN5b1-4 cells are sensitive to crowding, and protein production was expected to drop for the high cell densities (50).

For Sf9 cells (Figure 1B), the highest level of ER $\beta$ production was obtained for the $4.25 \times 10^{6}$ cells/well at three to four days post-infection (Figure 1B). The rate of protein production at this density lagged behind other wells that peaked earlier (close to two days after infection). Even at the highest cell density, the maximum amount of ER $\beta$ produced by Sf9 cells was less than that produced by the BTI-TN5b1-4 cells.
The Sf21 cell line produced more $E R \beta$ at an earlier time after infection compared to either the BTI-TN5b1-4 or Sf9 cell lines (Figure 1C). The highest level of ER $\beta$ production was obtained for the $7.5 \times 10^{5}$ cells/well, and this was achieved at 1.5 days after infection (Figure 1C). At the highest cell densities, the rate of ER $\beta$ production was lower. Like Sf9 cells, the highest density of Sf21 cells initially produced the lowest amount of ER $\beta$, but at time points later in infection, more $\operatorname{ER} \beta$ was produced at the higher cell densities compared to the lower cell densities.

Figure 2 expresses ER $\beta$ production on a per cell basis. For the BTI-TN5b14 cell line, ER $\beta$ production at all cell densities was similar, from $2.5 \times 10^{5}$ to $7 \times 10^{5}$ cells/well and decreased to between $7 \times 10^{5}$ and $9 \times 10^{5}$ cells/well (Figure 2A). These data and those in

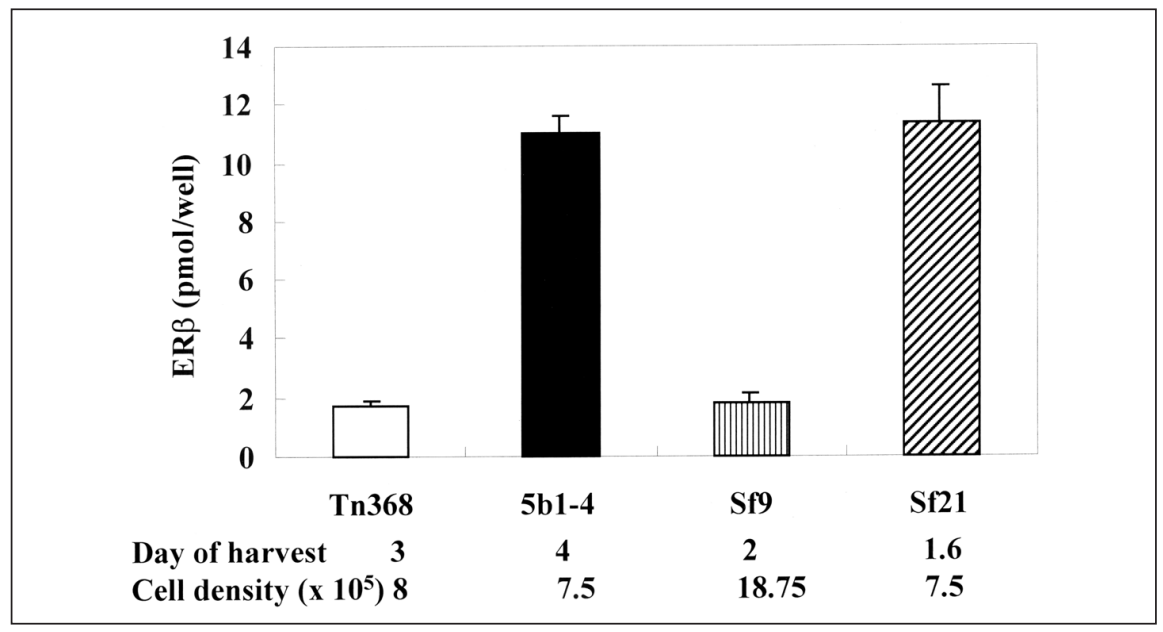

Figure 3. Comparison of maximum ER $\beta$ production in different cell lines. The amount of ER $\beta$ produced per well at the indicated cell densities and time of harvest post-infection was determined by HAP assay. Values are $\overline{\mathrm{x}} \pm$ SEM of triplicate determinations from a single experiment that are representative of two to three separate time course experiments, with the exception of Tn368 (first experiment). 5b1-4, BTI-TN5b1-4 cells.
Figure $1 \mathrm{~A}$ indicate that between $5.5 \times$ $10^{5}$ and $7 \times 10^{5}$ cells/well is the best cell density for ER $\beta$ production in BTITN5b1-4 cells.

For the Sf9 cell line (Figure 2B), ER $\beta$ production was much lower at the highest cell density tested than at lower cell densities. One explanation for this decrease in ER $\beta$ production is that protein integrity and function might be compromised under these conditions. In the range of cell densities tested, Sf21 demonstrated a high sensitivity of ER $\beta$ production to cell density. On a per well basis, the peak ER $\beta$ production was observed at $7.5 \times 10^{5}$ cells/well; but at that density, ER $\beta$ production was about half the peak ER $\beta$ at $3.5 \times 10^{5}$ cells/well.

Figure 3 shows a comparison of ER $\beta$ production at the optimal cell densities determined in the preceding sets of experiments. These data show that $\operatorname{Tn} 368$ and Sf9 produce approximately 6-fold less ER $\beta$ than either the BTI-TN5b1-4 or Sf21 cell lines. Although ER $\beta$ production is comparable in BTI-TN5b1-4 and $\mathrm{Sf} 21$ cells, ER $\beta$ production in $\mathrm{Sf} 21$ cells peaks at an earlier time after infection (i.e., 1.6 days vs. 4 days for BTITN5b1-4). Therefore, it is more economical to produce large quantities of ER $\beta$ in Sf21 cells. An additional comparison of peak ER $\beta$ protein production is provided in Table 1 . The affinity of $E_{2}$ binding to ER $\beta$ harvested from Sf21 cells was calculated to be a $\mathrm{K}_{\mathrm{d}}=2.6 \pm$ $0.2 \mathrm{nM}$ (data not shown).

\section{ERE Binding Activity of Baculovirus-Expressed ER $\beta$}

In addition to ligand binding, DNA binding is the second biological activi- 
ty essential for steroid receptor function. We employed EMSA to examine if the amount of ER $\beta$ determined by the HAP assay correlated with the estrogen response element (ERE) DNA binding activity and to compare the ERE binding activity of ER $\beta$ produced by the different insect cell lines. We compared ER $\beta$ binding using a fixed amount, 89 fmol ER $\beta$ [determined by $\left[{ }^{3} \mathrm{H}\right] \mathrm{E}_{2}$ binding (36)], and a fixed concentration, $65 \mathrm{fmol}\left[{ }^{32} \mathrm{P}\right] \mathrm{ERE}$ (Figure

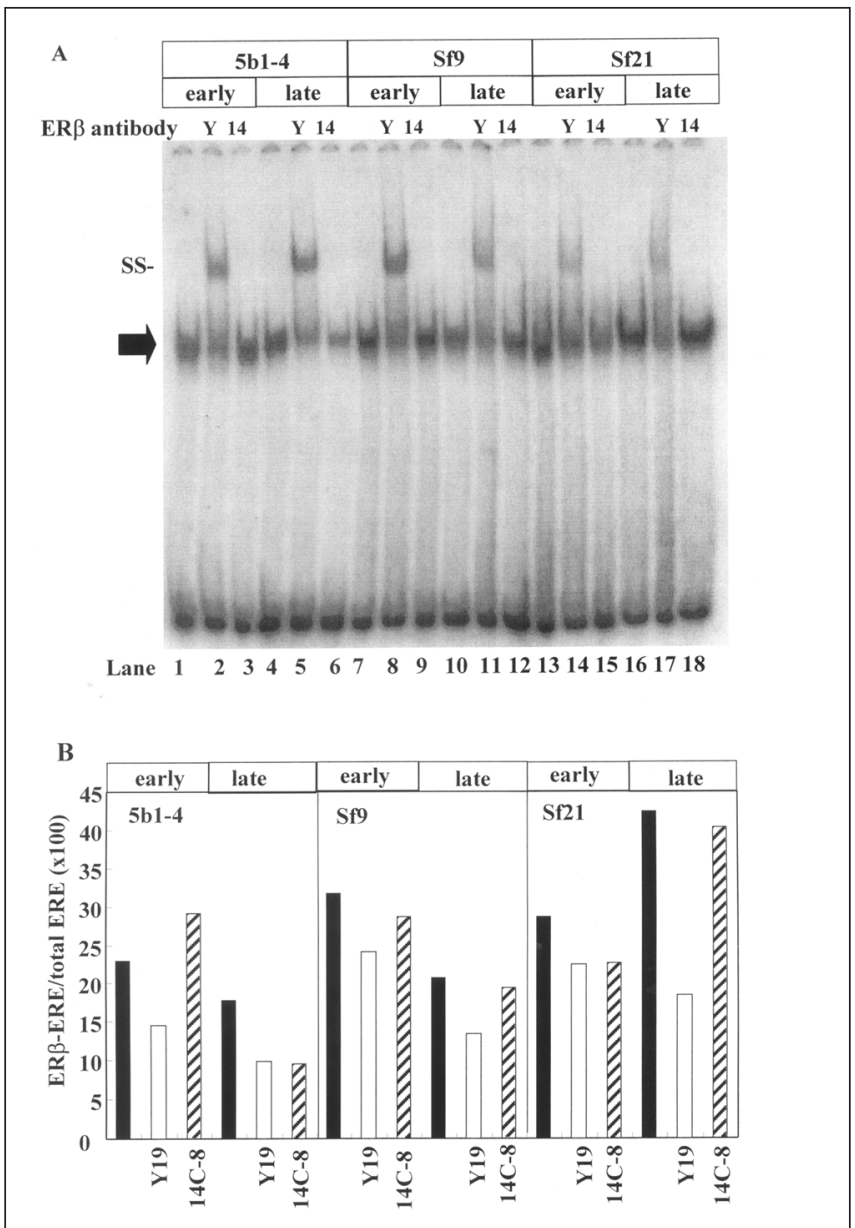

Figure 4. Recombinant ER $\beta$ binds EREs. (A) EMSA of ER $\beta$-ERE binding. Identical ER $\beta$ concentrations ( $89 \mathrm{fmol}$ ) in nuclear extracts harvested early (3.7, 1.8 , or 1.5 days) or late after infection at $(4.7,2.5$, or 2.5 days) for BTITN5b1-4, Sf9, and Sf-21 cells, respectively, were incubated with [32P]EREc38 as described in the Materials and Methods section. ER $\beta$-specific antibodies Y-19 (indicated as "Y") and 14C8 (indicated as "14") were added to the designated reactions. The arrow indicates the specific ER $\beta$ EREc38 band, and SS- indicates the supershifted complex formed between the ER $\beta$ antibody Y-19 and the ER $\beta$-EREc38 complex. EMSA details are provided in the text. This autoradiograph is representative of four independent EMSA experiments that show similar results. (B) The data from panel A were quantitated as described in the text, and the [32P]dpm converted was into percentages of the ER $\beta$-EREc38 complex. The solid bars indicate the amount of ER $\beta$-ERE complex formed with no added antibody, and the open and hatched bars indicate the amounts of ER $\beta$-ERE complex formed with the addition of ER $\beta$ antibodies Y19 and 14C-8, respectively. 5b1-4, BTI-TN5b1-4 cells. harvest (Figure 4B). The amount of ER $\beta$ binding was comparable among the cell lines. However, ER $\beta$ produced by $\mathrm{Sf} 21$ cells appeared to have greater ERE binding at the later harvest time point than BTI-TN5b1-4 and or Sf9 cells (Table 1).

\section{Western Blot Analysis of Baculovirus-Expressed ER $\beta$}

We also assessed immunoreactive ER $\beta$ protein production by Western blot anaysis using two different ER $\beta$ specific antibodies (Figure 5). The CWK-F12 epitope is aa (amino acid) 272-285 in the human ER $\beta$ ligand binding domain, and PA1-311 was raised against aa $45-55$ of rat ER $\beta$. Identical results were obtained with the two antibodies: two bands of 54 and 50

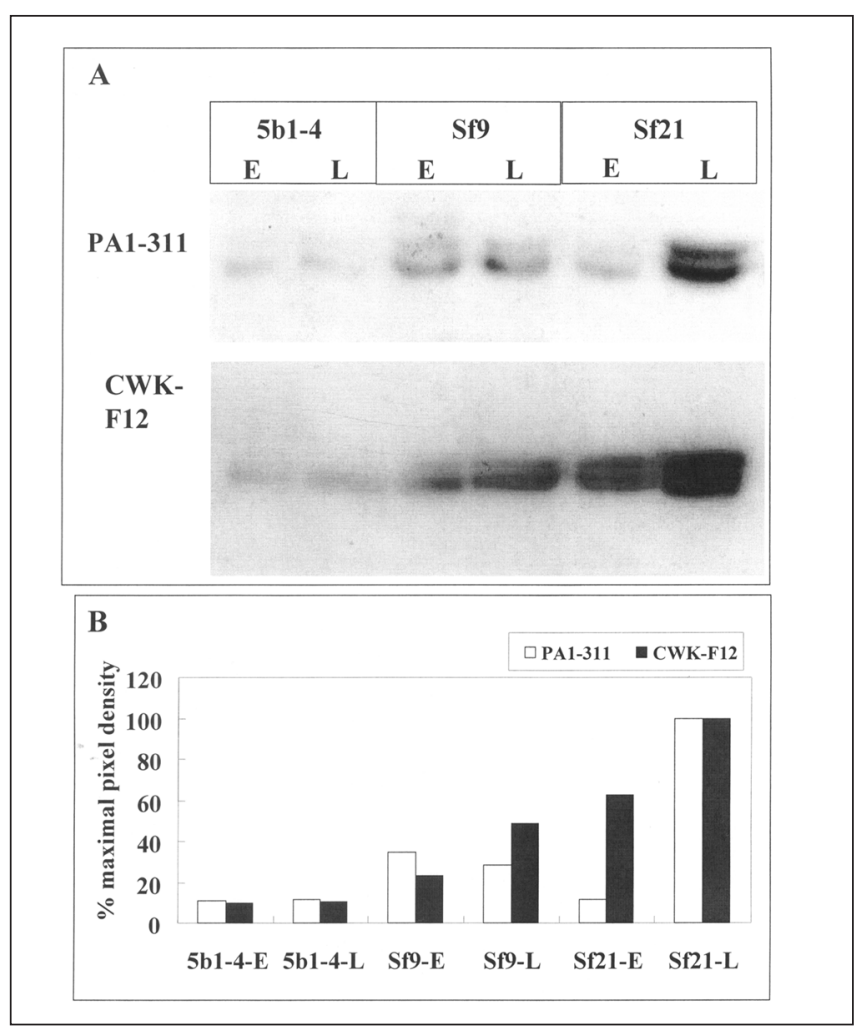

Figure 5. Western blot of ER $\beta$ protein production. (A) Identical amounts of protein $(30 \mu \mathrm{g})$ from cell extracts of rat ER $\beta$ baculovirus-infected BTITN5b1-4, Sf9, and Sf21 cells harvested early $(3.7,1.8$, or 1.5 days) or late after infection $(4.7,2.5$, or 2.5 days), respectively, were separated by $10 \%$ SDSPAGE. The resulting PVDF membrane was probed with ER $\beta$-specific antisera PA1-311 or monoclonal CWK-F12 ER $\beta$ antibody (13) as described in the Materials and Methods section. (B) The blots shown in panel A were quantitated as described in the text. Shown here is the percent of maximal pixel density in each blot, using the pixel density detected in Sf $21 \mathrm{~L}$ as $100 \%$. These data are from a single representative experiment that has been repeated with similar results. 5b1-4, BTI-TN5b1-4 cells. 
$\mathrm{kDa}$ were observed. The calculated molecular weight of ER $\beta$ was $54.2 \mathrm{kDa}$ (27), which accounted for the 54-kDa band. We suggest that the $50 \mathrm{kDa}$ band may be the result of incomplete translation, partial protein degradation during sample processing, or incomplete glycosylation or phosphorylation.

\section{Use of Baculovirus-Expressed ER $\beta$ to Measure ERE Binding Affinity}

Competition EMSA (46) was used to calculate the affinity of baculovirusexpressed ER $\beta$ binding to EREc38. ER $\beta$ binds EREc38, which has a "perfect" palindromic ERE, with high affinity $\left(\mathrm{K}_{\mathrm{d}}=0.72 \pm 0.20 \mathrm{nM}\right)$. These data indicate the utility of baculovirus-expressed ER $\beta$ for in vitro DNA binding affinity determinations.

\section{DISCUSSION}

The production of recombinant steroid and nuclear receptor proteins in the BEVS has predominantly used AcMNPV and the Sf9 cell line. Although comparisons of recombinant protein production with BEVS both from large-scale suspension culture and for smaller scale production in disposable flasks has been performed for proteins such as secreted placental alkaline phosphatase and $\beta$ - galactosidase (15), human muscarinic M2 (19) and dopamine D2 receptors (20), and DNA methyltransferase (38), this is the first comparison of the production of a nuclear receptor in different insect cell lines.

We examined ER $\beta$ production in four insect cell lines: Tn368, BTITN5b1-4, Sf9, and Sf21. The Sf9 cell line is a subclone of Sf21 and offers no particular advantage over Sf21 in adherent culture conditions (35). The widely used BTI-TN5b1-4 cells were developed for recombinant protein production and are more efficient secretors of exported proteins (15).

ER $\beta$ production was determined as a function of cell density and time after infection in Tn368, BTI-TN5b1-4, Sf9, and $\mathrm{Sf} 21$ cells. Our results show that Sf21 and BTI-TN5b1-4 cells produce more bioactive ER $\beta$ protein, based on $\left[{ }^{3} \mathrm{H}\right] \mathrm{E}_{2}$ and ERE binding activity in cell homogenates, as compared to Sf9 cells.
The ER $\beta$ produced in Sf21 cells shows 2- and 4-fold the specific activity of ER $\beta$ produced in Sf9 and BTI-TN5b14 cells, respectively. DNA binding activity, determined by ERE binding using EMSA, is more effectively preserved late in the infection cycle of Sf21 cells compared to the other two cell lines. An additional advantage of $\mathrm{Sf} 21$ cells is that they produced more immunoreactive $E R \beta / m g$ protein than did Sf9 or BTI-TN5b1-4 cells. Moreover, because ER $\beta$ production in Sf 21 cells peaks at an earlier time after infection (i.e., 1.6 days), we conclude that it is more economical to produce $\mathrm{ER} \beta$ on this scale in $\mathrm{Sf} 21$ cells.

The maximum level of ER $\beta$ produced in Sf21 cells reported here was $18 \mathrm{pmol} \mathrm{ER} \beta$ dimer/mg protein, which is $36 \mathrm{pmol} \mathrm{ER} \beta$ monomer $/ \mathrm{mg}$ protein (Table 1). This result is comparable with the value of $32.8 \mathrm{pmol} / \mathrm{mg}$ protein for chicken ER $\alpha$ (8) but lower than the 230 pmol ER $\alpha$ monomer/mg produced $111 \mathrm{~h}$ post-infection in the Sf9 cells (34). Compared to other steroid and nuclear receptors, we observed higher ER $\beta$ production in Sf21 cells than the 5-10 pmol androgen receptor/mg protein $(21)$ or the $3.8 \mathrm{pmol} \mathrm{hPR}-\mathrm{A} / \mathrm{mg}$ protein (14) observed in Sf9 cells but lower than the $1200 \mathrm{pmol} h \mathrm{hR} \alpha 1 / \mathrm{mg}$ nuclear protein produced in $\mathrm{Sf} 9$ cells (39). Unfortunately, we cannot compare our results for the production of rat ER $\beta$ with those for the short form (485 aa) of hER $\beta$ in Sf21 cells because no quantitation was provided (17).

In summary, we have shown that the Sf21 cell line is superior to the commonly used Sf9 cell line for the production of biologically active recombinant ER $\beta$. Baculovirus-expressed ER $\beta$ bound EREs with high affinity in vitro, indicating the utility of this method of ER production for functional measures of ER activity. The clear superiority of Sf 21 cells for ER $\beta$ production should encourage this type of comparison for other nuclear receptors by other investigators since the choice of cell type can dramatically influence yield and purity.

\section{ACKNOWLEDGMENTS}

We thank Dr. Jan-Ake Gustafsson for providing the rat $\mathrm{ER} \beta \mathrm{cDNA}$ and
Dr. Benita S. Katzenellenbogen for providing the CWK-F12 ER $\beta$ antibody. We thank Avedis Kazanjian for his assistance in early experiments, Dr. Rhona E. Felzer for her comments on this manuscript, Dr. K. Cameron Falkner for his advice and assistance in PCR cloning, and Dr. Valentyn V. Tyulmenkov for determining the $E_{2}$-ER $\beta$ binding affinity. Supported by grant no. NIH R01 DK 53220 from the National Institutes of Health and a University of Louisville School of Medicine research grant to C.M.K.

\section{REFERENCES}

1.Anderson, I., C.R. Bartley, R.A. Lerch, W.G. Gray, P.D. Friesen, and J. Gorski. 1998. Estrogen receptor $\alpha$ requires no accessory factors for high-affinity binding to a consensus response element. Biochemistry 37:1728717298.

2.Arnold, S.F., J.D. Obourn, H. Jaffe, and A.C. Notides. 1994. Serine 167 is the major estradiol-induced phosphorylation site on the human estrogen receptor. Mol. Endocrinol. 8:1208-1214.

3.Arnold, S.F., J.D. Obourn, M.R. Yudt, T.H. Carter, and A.C. Notides. 1995. In vivo and in vitro phosphorylation of the human estrogen receptor. J. Steroid Biochem. Mol. Biol. 52:159-171

4.Arnold, S.F., D.P. Vorojeikina, and A.C. Notides. 1995. Phosphorylation of tyrosine 537 on the human estrogen receptor is required for binding to an estrogen response element. J. Biol. Chem. 270:30205-30212

5.Ayres, M.D., S.C. Howard, J. Kuzio, M. Lopez-Ferber, and R.D. Possee. 1994. The complete DNA sequence of Autographa californica nuclear polyhedrosis virus. Virology 202:586-605.

6.Beekman, J.M., G.F. Allan, S.Y. Tsai, M.-J. Tsai, and B.W. O'Malley. 1993. Transcriptional activation by the estrogen receptor requires a conformational change in the ligand binding domain. Mol. Endocrinol. 7:12661274.

7.Beekman, J.M., A.J. Cooney, J.F. Elliston, S.Y. Tsai, and M.J. Tsai. 1994. A rapid onestep method to purify baculovirus-expressed human estrogen receptor to be used in the analysis of the oxytocin promoter. Gene 146:285-289.

8.Binart, N., M. Lombes, and E.E. Baulieu. 1995. Distinct functions of the $90 \mathrm{kDa}$ heatshock protein (hsp90) in oestrogen and mineralocorticosteroid receptor activity: effects of hsp90 deletion mutants. Biochem. J. 311:797804.

9.Brown, M. and P.A. Sharp. 1990. Human estrogen receptor forms multiple protein-DNA complexes. J. Biol. Chem. 265:11238-11243.

10.Castano, E., C.W. Chen, D.P. Vorojeikina, and A.C. Notides. 1998. The role of phosphorylation in human estrogen receptor function. 
J. Steroid Biochem. Mol. Biol. 65:101-110.

11.Cheng, X., R.N. Cole, J. Zaia, and G.W Hart. 2000. Alternative O-glycosylation/Ophosphorylation of the murine estrogen receptor $\beta$. Biochemistry 39:11609-11620.

12.Cheng, X. and G.W. Hart. 2001. Alternative O-glycosylation/O-phosphorylation of serine16 in murine estrogen receptor $\beta$ : post-translational regulation of turnover and transactivation activity. J. Biol. Chem. 276:10570-10575.

13.Choi, I., C. Ko, O. Park-Sarge, R. Nie, R.A. Hess, C. Graves, and B.S. Katzenellenbogen. 2001. Human estrogen receptor $\beta$-specific monoclonal antibodies: characterization and use in studies of estrogen receptor $\beta$ protein expression in reproductive tissues. Mol. Cell. Endocrinol. 181:139-150.

14.Christensen, K., P.A. Estes, S.A. Onate, C.A. Beck, A. DeMarzo, M. Altmann, B.A. Lieberman, J. St. John, et al. 1991. Characterization and functional properties of the A and $\mathrm{B}$ forms of human progesterone receptors synthesized in a baculovirus system. Mol. Endocrinol. 5:1755-1770.

15.Davis, T.R., T.J. Wickham, K.A. McKenna, R.R. Granados, M.L. Shuler, and H.A. Wood. 1993. Comparative recombinant protein production of eight insect cell lines. In Vitro Cell Dev. Biol. Anim. 29A:388-390.

16.Fawell, S.E., R. White, S. Hoare, M. Sydenham, M. Page, and M.G. Parker. 1990. Inhibition of estrogen receptor-DNA binding by the "pure" antiestrogen ICI 164384 appears to be mediated by impaired receptor dimerization. Proc. Natl. Acad. Sci. USA 87:68836887.

17.Greco, B., E.A. Allegretto, M.J. Tetel, and J.D. Blaustein. 2001. Coexpression of ER $\beta$ with $E R \alpha$ and progestin receptor proteins in the female rat forebrain: effects of estradiol treatment. Endocrinology 142:5172-5181.

18.Green, S., P. Walter, V. Kumar, A. Krust, J.M. Bornert, P. Argos, and P. Chambon. 1986. Human oestrogen receptor cDNA: sequence, expression and homology to v- erb-A. Nature 320:134-139.

19.Heitz, F., C. Nay, and C. Guenet. 1997. Expression of functional human muscarinic M2 receptors in different insect cell lines. J. Recept. Signal Transduct. Res. 17:305-317.

20.Javitch, J.A., J. Kaback, X. Li, and A. Karlin. 1994. Expression and characterization of human dopamine D2 receptor in baculovirusinfected insect cells. J. Recept. Res. 14:99-117.

21.Kallio, P.J., J.J. Palvimo, M. Mehto, and O.A. Janne. 1994. Analysis of androgen receptor-DNA interactions with receptor proteins produced in insect cells. J. Biol. Chem. 269:11514-11522.

22.Klinge, C.M., R.A. Bambara, S. Zain, and R. Hilf. 1987. Estrogen receptor binding to nuclei from normal and neoplastic rat mammary tissues in vitro. Cancer Res. 47:2852-2859.

23.Klinge, C.M., S.C. Jernigan, S.L. Smith, V.V. Tyulmenkov, and P.C. Kulakosky. 2001. Estrogen response element sequence impacts the conformation and transcriptional activity of estrogen receptor $\alpha$. Mol. Cell. Endocrinol. 174:151-166.

24.Klinge, C.M., A.M. Traish, R.A. Bambara, and R. Hilf. 1996. Dissociation of 4-hydroxytamoxifen, but not estradiol or tamoxifen aziri- dine, from the estrogen receptor when the receptor binds estrogen response element DNA. J. Steroid Biochem. Mol. Biol. 57:51-66.

25.Kost, T.A. and J.P. Condreay. 1999. Recombinant baculoviruses as expression vectors for insect and mammalian cells. Curr. Opin. Biotechnol. 10:428-433.

26.Kuiper, G.G., B. Carlsson, J. Grandien, E. Enmark, J. Haggblad, S. Nilsson, and J.-A. Gustafsson. 1997. Comparison of the ligand binding specificity and transcript tissue distribution of estrogen receptors $\alpha$ and $\beta$. Endocrinology 138:863-870.

27.Kuiper, G.G., E. Enmark, M. Pelto-Huikko, S. Nilsson, and J.-A. Gustafsson. 1996 Cloning of a novel estrogen receptor expressed in rat prostate and ovary. Proc. Natl. Acad. Sci. USA 93:5925-5930.

28.Kuiper, G.G., P.J. Shughrue, I. Merchenthaler, and J.A. Gustafsson. 1998. The estrogen receptor $\beta$ subtype: a novel mediator of estrogen action in neuroendocrine systems. Front. Neuroendocrinol. 19:253-286.

29.Kulakosky, P.C., S.C. Jernigan, M.A. Mc Carty, and C.M. Klinge. 2002. Response element sequence regulates estrogen receptor $\alpha$ and $\beta$ affinity and activity. J. Mol. Endocrinol. 29:137-152.

30.Maglich, J.M., A. Sluder, X. Guan, Y. Shi, D.D. McKee, K. Carrick, K. Kamdar, T.M. Willson, et al. 2001. Comparison of complete nuclear receptor sets from the human, Caenorhabditis elegans and Drosophila genomes. Genome Biol. 2:RESEARCH0029.

31.Metzger, D., J.H. White, and P. Chambon. 1988. The human oestrogen receptor functions in yeast. Nature 334:31-36.

32.Miller, L.K. 1988. Baculoviruses as gene expression vectors. Annu. Rev. Microbiol 42:177-199.

33.Miller, L.K. 1993. Baculoviruses: high-level expression in insect cells. Curr. Opin. Genet. Dev. 3:97-101.

34.Obourn, J.D., N.J. Koszewski, and A.C. Notides. 1993. Hormone- and DNA-binding mechanisms of the recombinant human estrogen receptor. Biochemistry 32:6229-6236.

35.Pasumarthy, M.K. and D.W. Murhammer. 1994. Clonal variation in the Spodoptera frugiperda IPLB-SF21-AE insect cell population. Biotechnol. Prog. 10:314-319.

36.Pavlik, E.J. and P.B. Coulson. 1976. Hydroxylapatite "batch" assay for estrogen receptor: increased sensitivity over present receptor assays. J. Steroid Biochem. 7:357-368.

37.Power, R.F., O.M. Conneely, D.P. McDonnell, J.H. Clark, T.R. Butt, W.T. Schrader, and B.W. O'Malley. 1990. High level expression of a truncated chicken progesterone receptor in Escherichia coli. J. Biol. Chem. 265:1419-1424.

38.Pradhan, S., D. Talbot, M. Sha, J. Benner, L. Hornstra, E. Li, R. Jaenisch, and R.J. Roberts. 1997. Baculovirus-mediated expression and characterization of the full-length murine DNA methyltransferase. Nucleic Acids Res. 25:4666-4673.

39.Quick, T.C., A.M. Traish, and R.M. Niles. 1994. Characterization of human retinoic acid receptor a1 expressed in recombinant baculovirus-infected Sf9 insect cells. Receptor 4:65-80.
40.Skliris, G.P., P.J. Carder, M.R. Lansdown, and V. Speirs. 2001. Immunohistochemical detection of ER $\beta$ in breast cancer: towards more detailed receptor profiling? Br. J. Cancer 84:1095-1098.

41.Srinivasan, G. 1992. Overexpression of receptors of the steroid/thyroid family. Mol. Endocrinol. 6:857-860.

42.Thornton, J.W. 2001. Evolution of vertebrate steroid receptors from an ancestral estrogen receptor by ligand exploitation and serial genome expansions. Proc. Natl. Acad. Sci. USA 98:5671-5676.

43.Tora, L., A. Mullick, D. Metzger, M. Ponglikitmongkol, I. Park, and P. Chambon. 1989. The cloned human oestrogen receptor contains a mutation which alters its hormone binding properties. EMBO J. 8:1981-1986.

44.Tyulmenkov, V.T., S.C. Jernigan, and C.M Klinge. 2000. Comparison of transcriptional synergy of estrogen receptors $\alpha$ and $\beta$ from multiple tandem estrogen response elements. Mol. Cell. Endocrinol. 165:151-161.

45.Tyulmenkov, V.T., and C.M. Klinge. 2000 Selectivity of detection of estrogen receptors $\alpha$ and $\beta$ with cognate antibodies in electrophoretic mobility shift assay. Steroids 65:505-512.

46.Tyulmenkov, V.V. and C.M. Klinge. 2001. A mathematical approach to predict the affinity of estrogen receptors $\alpha$ and $\beta$ binding to DNA. Mol. Cell. Endocrinol. 182:109-119.

47.Verrier, C.S., N. Roodi, C.J. Yee, L.R. Bailey, R.A. Jensen, M. Bustin, and F.F. Parl. 1997. High-mobility group (HMG) protein HMG-1 and TATA-binding protein-associated factor TAF(II)30 affect estrogen receptor-mediated transcriptional activation. Mol. Endocrinol. 11:1009-1019.

48.Wang, C., M. Fu, R.H. Angeletti, L. Siconolfi-Baez, A.T. Reutens, C. Albanese, M.P. Lisanti, B.S. Katzenellenbogen, et al. 2001. Direct acetylation of the estrogen receptor $\alpha$ hinge region by p300 regulates transactivation and hormone sensitivity. J. Biol. Chem. 276:18375-18383.

49.Wickham, T.J., T. Davis, R.R. Granados, M.L. Shuler, and H.A. Wood. 1992. Screening of insect cell lines for the production of recombinant proteins and infectious virus in the baculovirus expression system. Biotechnol. Prog. 8:391-396.

50.Wickham, T.J. and G.R. Nemerow. 1993. Optimization of growth methods and recombinant protein production in BTI-Tn-5B1-4 insect cells using the baculovirus expression system. Biotechnol. Prog. 9:25-30.

51.Wood, H.A. 1977. An agar overlay plaque assay method for Autographa califonica nuclear polyhedrosis virus. J. Invertebr. Pathol. 29:304-307

Received 3 September 2002; accepted 30 October 2002

Address correspondence to:

Dr. Carolyn M. Klinge

Department of Biochemistry \& Molecular Biology University of Louisville School of Medicine

Louisville, KY 40292, USA

e-mail carolyn.klinge@louisville.edu 